\title{
Distribution and habitats of the alien invader freshwater snail Physa acuta in South Africa
}

\author{
KN de Kock* and CT Wolmarans \\ School of Environmental Sciences and Development, Zoology, Potchefstroom Campus of the North-West University, \\ Private Bag X6001, Potchefstroom 2520, South Africa
}

\begin{abstract}
This article focuses on the geographical distribution and habitats of the invader freshwater snail species Physa acuta as reflected by samples taken from 758 collection sites on record in the database of the National Freshwater Snail Collection (NFSC) at the Potchefstroom Campus of the North-West University. This species is currently the second most widespread alien invader freshwater snail species in South Africa. The 121 different loci $(1 / 16$ - degree squares) from which the samples were collected, reflect a wide but discontinuous distribution mainly clustered around the major ports and urban centres of South Africa. Details of each habitat as described by collectors during surveys were statistically analysed, as well as altitude and mean annual air temperatures and rainfall for each locality. This species was reported from all types of water-bodies represented in the database, but the largest number of samples was recovered from dams and rivers. Chi-square and effect size values were calculated and an integrated decision tree constructed from the data which indicated that temperature, altitude and types of water-bodies were the important factors that significantly influenced the distribution of $P$. acuta in South Africa. Its slow progress in invading the relatively undisturbed water-bodies in the Kruger National Park as compared to the recently introduced invader freshwater snail species, Tarebia granifera, is briefly discussed.
\end{abstract}

Keywords: Physa acuta, invasive species, freshwater snail, geographical distribution, habitat preferences

\section{Introduction}

Physa acuta was not mentioned in the monograph by Connollyi (1939) after an in-depth revision of extensive mollusc material collected by himself and many other researchers in South Africa. Although the oldest record of Physa acuta in the National Freshwater Snail Collection (NFSC) dates back to 1954 from the Umsindusi River (KwaZulu-Natal), the first report in print for South Africa was established in 1964 by Van Bruggen (1964) from a single locality in Pretoria. Since then it has invaded many water-bodies in several river systems in South Africa (Hamilton-Attwell et al., 1970; De Kock et al., 1989; Appleton, 2003) and is currently considered the second most widespread alien invasive freshwater snail species in this country. In their review of introduced freshwater snails worldwide, Madsen and Frandsen (1989) concluded that the aquarium trade was probably to blame for the distribution of several of the common species, including P. acuta, a view supported by Appleton (2003) in his account of the alien and invasive freshwater gastropods in South Africa. Physa acuta which is widespread in water-bodies of the old world may have originated in North America and has become invasive on 4 continents (Appleton, 2003). According to Dillon et al. (2002) the identification of a new-world cognate has been complicated by the confused systematics and taxonomy of the Physidae in America and more than 40 species of physids are currently recognised in the United States. However, in the course of their research these authors were unable to detect evidence of reproductive isolation among six populations

* To whom all correspondence should be addressed.

䱇 +2718 299-2380; fax: +2718 299-2370;

e-mail: kenne.dekock@nwu.ac.za

Received 24 April 2007; accepted in revised form 5 July 2007. of snails from two continents and came to the conclusion that all should be referred to the oldest available nomen, P. acuta. On the strength of results of a taxonomic study by Hamilton-Attwell et al. (1970), the 200 samples of Physidae on record in the database of the NFSC at that stage, were identified as $P$. acuta. The remainder of the total number of 758 samples on record in the database for this species were also subsequently identified as P. acuta.

The first report in print of the presence of Aplexa marmorata, another species of the physid family in South Africa, was by Appleton et al. (1989) from specimens collected near Durban, KwaZulu-Natal in 1986. According to Appleton (2003) it has since then become widespread in the Durban area. The presence of A. marmorata was also established in 11 water-bodies in surveys conducted in the Kruger National Park since 1995 (De Kock and Wolmarans, 1998; De Kock et al., 2002; Wolmarans and De Kock, 2006). According to Appleton and Dana (2005) this invader species could have been introduced to Mozambique a century earlier than its first discovery in South Africa. The shell of A. marmorata can quite easily be confused with that of P. acuta; however, the posterior end of the foot of A. marmorata is darkly pigmented and pencil-like and its copulatory organ differs from that of $P$. acuta in that it does not have a conspicuous, externally visible preputial gland (Appleton et al., 1989).

Extensive research has been done in South Africa on several aspects of the biology of $P$. acuta (Appleton and Brackenbury, 1989; Appleton and Branch, 1989; Brackenbury and Appleton, 1991); Brackenbury and Appleton, 1993). The geographical distribution of this species in South Africa was reported by Hamilton-Attwell et al. (1970) and updated by De Kock et al. (1989).

By comparison with the freshwater snail genera Bulinus and Biomphalaria which are well-known intermediate hosts of human and animal diseases, $P$. acuta is rather innocuous having no role in transmission of any significant snail-borne disease. 
However, due to its superior reproductive capacity (Appleton and Brackenbury, 1998), ability to migrate upstream (Appleton and Branch, 1989) and to quickly recolonise a water-body (Brackenbury and Appleton, 1993), amongst others, this species could have a negative impact on indigenous freshwater molluscs in particular and on the biodiversity of freshwater habitats in general. This paper focuses on the geographical distribution and habitats of P. acuta currently on record for South Africa in the NFSC database.

\section{Methods}

Details of the habitats of all samples of P. acuta that could be located on a 1:250 000 topo-cadastral map series of South Africa, dating from 1956 until 2007, were extracted from the NFSC database. The number of loci $(1 / 16$ square degrees $)$ in which the collection sites were located, was distributed in intervals of mean annual air temperature and rainfall, as well as intervals of mean altitude, to illustrate the frequency of occurrence of this species within specific intervals. Rainfall, temperature and altitude data were obtained in 2001 from the Computing Centre for Water Research, University of KwaZuluNatal (disbanded since). A temperature index was calculated for all mollusc species in the database from their frequencies of occurrence within the selected temperature intervals and the results used to rank them in order of association with low to high climatic temperatures. The method of calculation is discussed in detail in our earlier publications (De Kock and Wolmarans, 2005a; b). Chi-square values were calculated to determine the significance in difference between the frequency of occurrence in, on, or at the different options for each variable, such as type of water-body, type of substratum or temperature interval. In addition an effect size (Cohen, 1977) was calculated for all the different variables discussed in this paper. The effect size is an index which measures the degree of discrepancy between the frequency distribution of a given species in the set of alternatives for a given variable such as water-bodies, as compared to the frequency distribution of all other mollusc species in the database in the set of alternatives for the same variable (Cohen, 1977). According to this author values for this index in the order of 0.1 and 0.3 indicate small and moderate effects respectively, while values in the order of 0.5 and higher indicate practically significant large effects. More details of the significance and interpretation of specific values calculated for this statistic in a given situation, is discussed in our earlier publications (De Kock and Wolmarans, 2005a; b).

An integrated decision tree (Breiman et al., 1984) was also constructed from the data. This statistical model enables the selection and ranking of those variables that can maximally discriminate between the frequency of occurrence of a given species under specific conditions when compared to all other species in the database. This was accomplished by making use of the SAS Enterprise Miner for Windows NT Release 4.0, April 19, 2000 programme and Decision Tree Modelling Course Notes (Potts, 1999).

\section{Results}

The 758 samples of $P$. acuta that could be pinpointed on our maps were collected from 121 different loci of which 57 were reported earlier by Hamilton-Attwell et al. (1970) and an additional 43 by De Kock et al. (1989) (Fig. 1). Although this species was reported from all types of water-bodies represented in our database, the largest number of samples was collected in dams

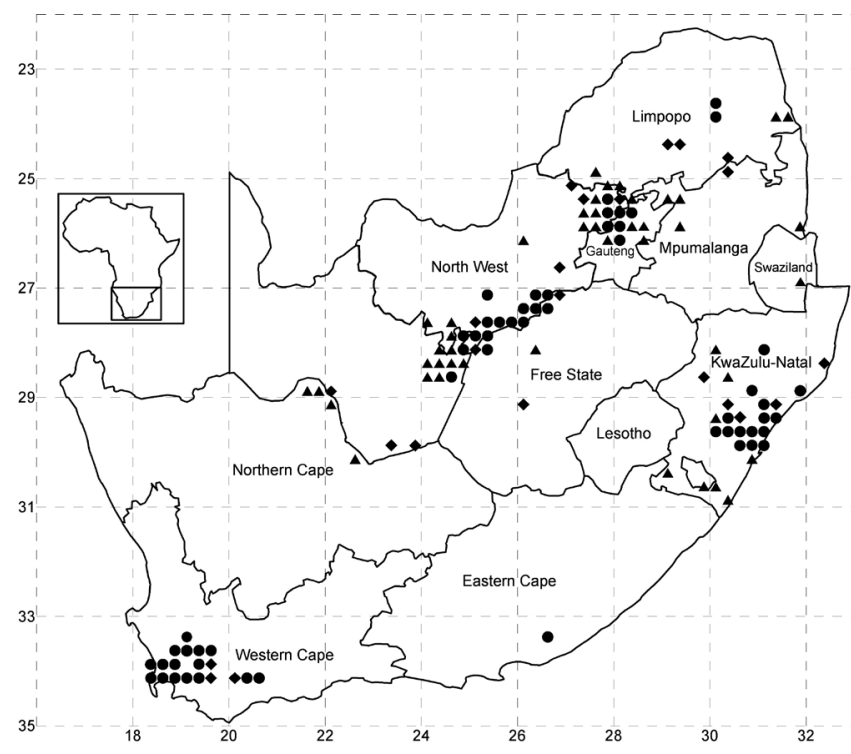

Figure 1

The geographical distribution of Physa acuta in $1 / 16$ square degree loci in South Africa.

- loci reported by Hamilton-Attwell et al. (1970)

- loci reported by De Kock et al. (1989)

- loci recorded in the database of the NFSC since 1989

TABLE 1

Types of water-bodies in which Physa acuta was found in 758 collection sites recorded during surveys

\begin{tabular}{|c|c|c|c|c|}
\hline Water-bodies & A & B & C & D \\
\hline Channel & 8 & $1.1 \%$ & 169 & $4.7 \%$ \\
\hline Concrete dam & 4 & $0.5 \%$ & 221 & $1.8 \%$ \\
\hline Dam & 253 & $33.3 \%$ & 8400 & $3.1 \%$ \\
\hline Ditch & 24 & $3.2 \%$ & 636 & $3.8 \%$ \\
\hline Irrigation furrow & 6 & $0.8 \%$ & 113 & $5.3 \%$ \\
\hline Pan & 1 & $0.1 \%$ & 306 & $0.3 \%$ \\
\hline Pond & 7 & $0.9 \%$ & 1566 & $0.4 \%$ \\
\hline Quarry & 2 & $0.3 \%$ & 122 & $1.6 \%$ \\
\hline River & 162 & $21.4 \%$ & 7507 & $2.2 \%$ \\
\hline Spring & 8 & $1.1 \%$ & 301 & $2.7 \%$ \\
\hline Stream & 88 & $11.6 \%$ & 7211 & $1.2 \%$ \\
\hline Swamp/Marsh & 25 & $3.3 \%$ & 2076 & $1.2 \%$ \\
\hline Vlei & 2 & $0.3 \%$ & 103 & $1.9 \%$ \\
\hline Waterhole & 11 & $1.5 \%$ & 225 & $4.9 \%$ \\
\hline \multicolumn{5}{|c|}{ Effect size $w=0.45$ (moderate to large) } \\
\hline \multicolumn{5}{|c|}{$\begin{array}{l}\text { A Number of times collected in a specific water-body } \\
B \% \text { of the total number of collections (758) on record for this } \\
\text { species } \\
\text { C Number of times any mollusc was collected in a specific } \\
\text { water-body } \\
D \% \text { occurrence of this species in the total number of collections } \\
\text { in a specific water-body }\end{array}$} \\
\hline
\end{tabular}

(253) and rivers (162) (Table 1). However, the samples recovered from irrigation furrows $(5.3 \%)$, water-holes $(4.9 \%)$, channels $(4.7 \%)$ and ditches $(3.8 \%)$ each represented a higher percentage of the total number of collections of any mollusc species in a specific water-body (Table 1). The frequency of occurrence of $P$. acuta in dams differed significantly from all the other types of water-bodies except from pans, ponds, rivers and swamps (chisquare values ranging from $\chi=34.18, d f=1 ; \mathrm{p}<0.05$ to $\chi=7.52, d f$ $=1 ; \mathrm{p}<0.05$ ). 
TABLE 2

Water conditions in the habitats of Physa acuta as described during surveys

\begin{tabular}{|l|c|c|c|c|c|c|c|c|c|}
\hline & \multicolumn{2}{|c|}{ Type } & \multicolumn{3}{|c|}{ Current speed } & \multicolumn{2}{c|}{ Turbidity } & \multicolumn{2}{c|}{ Salinity } \\
\cline { 2 - 11 } & Perennial & Seasonal & Fast & Slow & Standing & Clear & Muddy & Fresh & Brackish \\
\hline A & 518 & 49 & 56 & 210 & 310 & 443 & 92 & 335 & 15 \\
\hline B & $68.3 \%$ & $6.5 \%$ & $7.38 \%$ & $27.7 \%$ & $40.9 \%$ & $58.4 \%$ & $12.1 \%$ & $44.2 \%$ & $2.0 \%$ \\
\hline C & 22432 & 5350 & 2229 & 9501 & 16147 & 20408 & 6438 & 24089 & 657 \\
\hline D & $2.3 \%$ & $0.9 \%$ & $1.6 \%$ & $2.2 \%$ & $1.9 \%$ & $2.2 \%$ & $1.4 \%$ & $1.4 \%$ & $2.3 \%$ \\
\hline E & \multicolumn{3}{|c|}{$\begin{array}{l}\text { w } \\
\text { moderate effect) }\end{array}$} & \multicolumn{3}{|c|}{0.09 (small effect) } & $w=0.16$ (small effect) & $w=0.09$ (small effect) \\
\hline
\end{tabular}

A Number of times collected in a specific water condition

$B \%$ of the total number of collections (758) on record for this species

C Number of times any mollusc was collected in a specific water condition

E Effect size values calculated for each factor

The largest number of samples by far was reported from habitats in which the water conditions were described as perennial, standing, clear and fresh (Table 2) and the presence of aquatic vegetation was recorded for $80.7 \%$ of the sampling sites. Its frequency of occurrence in habitats with perennial water differed significantly from that in seasonal water $(p<0.05)$ and a significant difference was likewise found between frequencies

\section{TABLE 3}

Substratum types in the habitats of Physa acuta as described during surveys

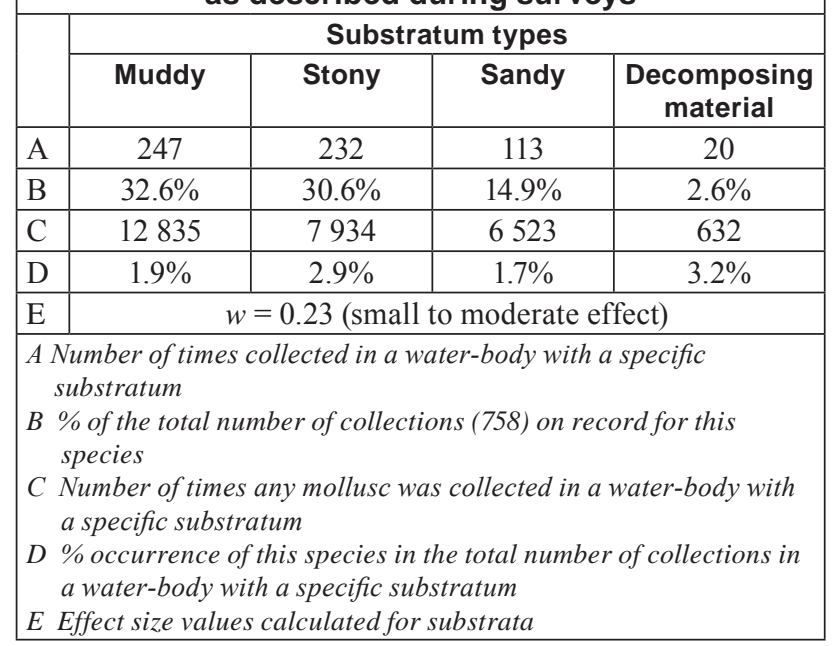

of occurrence in clear water as compared to the number of times it was reported from habitats with muddy water.

Although the frequency of occurrence reported for habitats with a stony substratum (232) was less than for habitats with a muddy substratum (247) it represented a higher percentage $(2.9 \%)$ of the total number of collections of any mollusc species in habitats with a specific substratum (Table 3). A significant difference could therefore be indicated between the frequencies of occurrence of this species in habitats with these two types of substrata $(\chi=21.75, \mathrm{df}=1 ; \mathrm{p}<0.05)$.

The largest number of samples was recovered from habitats with loci falling within the 16 to $20^{\circ} \mathrm{C}$ temperature interval (720) and this also represented a higher percentage (3.0\%) of the total number of collections within a specific interval (Table 4). The frequency of occurrence within this temperature interval therefore differed significantly from the interval ranging from 21 to $25^{\circ} \mathrm{C}(\chi=57.73, d f=1 ; \mathrm{p}<0.05)$. Regarding rainfall, $58.4 \%$ of the samples were recovered from loci falling within the interval ranging from 601 to $900 \mathrm{~mm}$. However, the 296 samples falling within the interval ranging from 301 to $600 \mathrm{~mm}$ represented a marginally higher percentage $(2.5 \%)$ of the frequency of occurrence of any mollusc species within a specific interval. No significant difference could be shown between the frequencies of occurrence of habitats falling within these two rainfall intervals $(\chi=1.75, d f=1 ; p>0.05)$. The majority of samples (582) were recovered from sites falling within the altitude interval ranging from 1001 to $1500 \mathrm{~m}$ and its frequency of occurrence within this interval differed significantly from all the other altitude

\begin{tabular}{|c|c|c|c|c|c|c|c|c|c|c|}
\hline \multicolumn{11}{|c|}{$\begin{array}{c}\text { TABLE } 4 \\
\begin{array}{c}\text { Frequency distribution of the } 758 \text { collection sites of Physa acuta in selected intervals of mean } \\
\text { annual air temperature and rainfall and mean altitude in South Africa }\end{array}\end{array}$} \\
\hline & \multicolumn{2}{|c|}{$\begin{array}{c}\text { Temperature inter- } \\
\text { vals }\left({ }^{\circ} \mathrm{C}\right)\end{array}$} & \multicolumn{4}{|c|}{ Rainfall intervals (mm) } & \multicolumn{4}{|c|}{ Altitude intervals (m) } \\
\hline & $\begin{array}{c}16 \\
-20\end{array}$ & $\begin{array}{c}21 \\
-25\end{array}$ & $\begin{array}{c}0 \\
-300\end{array}$ & $\begin{array}{c}301 \\
-600\end{array}$ & $\begin{array}{c}601 \\
-900\end{array}$ & $\begin{array}{l}901- \\
1200\end{array}$ & $\begin{array}{c}0 \\
-500\end{array}$ & $\begin{array}{c}501 \\
-1000\end{array}$ & $\begin{array}{c}1001 \\
-1500\end{array}$ & $\begin{array}{r}1501 \\
-2000\end{array}$ \\
\hline A & 720 & 38 & 12 & 296 & 443 & 7 & 114 & 36 & 582 & 26 \\
\hline B & $95.0 \%$ & $5.0 \%$ & $1.6 \%$ & $39.1 \%$ & $58.4 \%$ & $0.9 \%$ & $15.0 \%$ & $4.7 \%$ & $76.8 \%$ & $3.4 \%$ \\
\hline $\mathrm{C}$ & 24298 & 4276 & 975 & 11994 & 19799 & 1203 & 6747 & 4491 & 14918 & 6998 \\
\hline $\mathrm{D}$ & $3.0 \%$ & $0.9 \%$ & $1.2 \%$ & $2.5 \%$ & $2.2 \%$ & $5.8 \%$ & $1.7 \%$ & $0.8 \%$ & $3.9 \%$ & $0.37 \%$ \\
\hline E & \multicolumn{2}{|c|}{$\begin{array}{c}w=0.33 \\
\text { (moderate effect) }\end{array}$} & \multicolumn{4}{|c|}{$w=0.17$ (small effect) } & \multicolumn{4}{|c|}{$w=0.67$ (large effect) } \\
\hline \multicolumn{11}{|c|}{$\begin{array}{ll}\text { A Number of times collected in a locality falling within a specific interval } \\
B \text { \% of the total number of collections (758) on record for this species } \\
C \text { Number of times any mollusc was collected in a locality falling within a specific interval } \\
D \text { \% occurrence of this species in the total number of collections within a specific interval } \\
E \text { Effect size values calculated for each factor }\end{array}$} \\
\hline
\end{tabular}




\begin{tabular}{|c|c|c|c|c|c|c|c|c|c|c|}
\hline \multicolumn{11}{|c|}{$\begin{array}{c}\text { TABLE } 5 \\
\begin{array}{c}\text { Frequency distribution in temperature intervals and temperature index of Physa acuta as compared to } \\
\text { all mollusc species in the database of the National Freshwater Snail Collection }\end{array} \\
\end{array}$} \\
\hline Mollusc species & $\begin{array}{c}\begin{array}{c}\text { Number } \\
\text { of sam- } \\
\text { ples }\end{array} \\
\text { les }\end{array}$ & $5-10^{\circ} \mathrm{C}$ & $\begin{array}{c}11 \\
-15^{\circ} \mathrm{C}\end{array}$ & $\begin{array}{c}16 \\
-20^{\circ} \mathrm{C}\end{array}$ & $\begin{array}{c}21 \\
-25^{\circ} \mathrm{C}\end{array}$ & $\begin{array}{c}26 \\
-30^{\circ} \mathrm{C}\end{array}$ & ${ }^{1}$ Index & ${ }^{2} \mathrm{SD}$ & ${ }^{3} \mathrm{CV}$ & $\begin{array}{c}\text { Effect } \\
\text { size }\end{array}$ \\
\hline Pisidium viridarium & 636 & 201 & 270 & 163 & 2 & & 1.947 & 0.764 & 39.22 & -5.171 \\
\hline Lymnaea truncatula & 723 & 95 & 281 & 343 & 4 & & 2.354 & 0.709 & 30.14 & -3.258 \\
\hline Pisidium casertanum & 5 & & 2 & 3 & & & 2.600 & 0.548 & 21.07 & -2.103 \\
\hline Pisidium langleyanum & 627 & 18 & 173 & 430 & 6 & & 2.676 & 0.544 & 20.33 & -1.745 \\
\hline Pisidium costulosum & 425 & 1 & 138 & 282 & 4 & & 2.680 & 0.492 & 18.34 & -1.728 \\
\hline Bulinus tropicus & 8448 & 32 & 2326 & 5860 & 230 & & 2.744 & 0.502 & 18.31 & -1.426 \\
\hline Gyraulus connollyi & 969 & & 185 & 777 & 7 & & 2.816 & 0.406 & 14.40 & -1.088 \\
\hline Ceratophallus natalensis & 1797 & & 299 & 1430 & 68 & & 2.871 & 0.433 & 15.09 & -0.829 \\
\hline Burnupia (all species) & 2778 & 7 & 287 & 2384 & 100 & & 2.928 & 0.380 & 12.97 & -0.565 \\
\hline Ferrissia (all species) & 540 & & 72 & 420 & 47 & 1 & 2.957 & 0.476 & 16.09 & -0.425 \\
\hline Bulinus reticulatus & 296 & & 6 & 287 & 3 & & 2.990 & 0.174 & 5.83 & -0.273 \\
\hline Assiminea umlaasiana & 2 & & & 2 & & & 3.000 & 0.000 & 0.00 & -0.225 \\
\hline Tomichia cawstoni & 4 & & & 4 & & & 3.000 & 0.000 & 0.00 & -0.225 \\
\hline Tomichia diferens & 10 & & & 10 & & & 3.000 & 0.000 & 0.00 & -0.225 \\
\hline Tomichia lirata & 2 & & & 2 & & & 3.000 & 0.000 & 0.00 & -0.225 \\
\hline Tomichia ventricosa & 89 & & & 89 & & & 3.000 & 0.000 & 0.00 & -0.225 \\
\hline Tomichia tristis & 81 & & & 79 & 2 & & 3.025 & 0.156 & 5.16 & -0.109 \\
\hline Unio caffer & 76 & & 6 & 63 & 6 & 1 & 3.026 & 0.461 & 15.24 & -0.102 \\
\hline Physa acuta & 758 & & & 720 & 38 & & 3.048 & 0.213 & 7.00 & 0.000 \\
\hline Bulinus depressus & 552 & & & 519 & 33 & & 3.060 & 0.237 & 7.76 & 0.055 \\
\hline Arcuatula capensis & 15 & & & 14 & 1 & & 3.067 & 0.258 & 8.42 & 0.088 \\
\hline Lymnaea columella & 2302 & & 81 & 1977 & 243 & 1 & 3.071 & 0.371 & 12.07 & 0.109 \\
\hline Lymnaea natalensis & 4721 & & 205 & 3802 & 713 & 1 & 3.108 & 0.429 & 13.79 & 0.282 \\
\hline Assiminea bifasciata & 17 & & & 15 & 2 & & 3.118 & 0.332 & 10.65 & 0.327 \\
\hline Gyraulus costulatus & 736 & & 20 & 580 & 135 & 1 & 3.159 & 0.437 & 13.84 & 0.521 \\
\hline Bulinus forskalii & 1209 & & 17 & 985 & 204 & 3 & 3.160 & 0.409 & 12.95 & 0.524 \\
\hline Pisidium ovampicum & 6 & & & 5 & 1 & & 3.167 & 0.408 & 12.89 & 0.557 \\
\hline Sphaerium capense & 25 & & 1 & 17 & 7 & & 3.240 & 0.523 & 16.14 & 0.901 \\
\hline Bulinus africanus group & 2930 & & 9 & 2155 & 760 & 6 & 3.260 & 0.450 & 13.82 & 0.997 \\
\hline Corbicula fluminalis africana & 390 & & 1 & 291 & 94 & 4 & 3.267 & 0.437 & 13.38 & 1.030 \\
\hline Tomichia natalensis & 23 & & & 16 & 7 & & 3.304 & 0.470 & 14.24 & 1.204 \\
\hline Thiara amarula & 10 & & & 6 & 4 & & 3.400 & 0.516 & 15.19 & 1.653 \\
\hline Assiminea ovata & 5 & & & 3 & 2 & & 3.400 & 0.548 & 16.11 & 1.653 \\
\hline Melanoides victoriae & 49 & & & 29 & 19 & 1 & 3.429 & 0.540 & 15.75 & 1.787 \\
\hline Biomphalaria pfeifferi & 1639 & & 5 & 880 & 751 & 3 & 3.459 & 0.508 & 14.69 & 1.929 \\
\hline Septaria tesselaria & 2 & & & 1 & 1 & & 3.500 & 0.707 & 20.20 & 2.122 \\
\hline Coelatura framesi & 6 & & & 3 & 3 & & 3.500 & 0.548 & 15.65 & 2.122 \\
\hline Neritina natalensis & 16 & & & 8 & 8 & & 3.500 & 0.516 & 14.75 & 2.122 \\
\hline Bulinus natalensis & 245 & & 2 & 97 & 146 & & 3.588 & 0.510 & 14.20 & 2.534 \\
\hline Segmentorbis planodiscus & 27 & & & 9 & 18 & & 3.667 & 0.480 & 13.10 & 2.905 \\
\hline Segmentorbis angustus & 32 & & & 7 & 25 & & 3.781 & 0.420 & 11.11 & 3.442 \\
\hline Melanoides tuberculata & 305 & & & 64 & 237 & 4 & 3.803 & 0.430 & 11.30 & 3.546 \\
\hline Pisidium pirothi & 23 & & & 4 & 19 & & 3.826 & 0.388 & 10.13 & 3.653 \\
\hline Chambardia wahlbergi & 44 & & & 5 & 37 & 2 & 3.932 & 0.398 & 10.11 & 4.149 \\
\hline Aplexa marmorata & 9 & & & & 9 & & 4.000 & 0.000 & 0.00 & 4.469 \\
\hline Bellamya capillata & 31 & & & & 31 & & 4.000 & 0.000 & 0.00 & 4.469 \\
\hline Eupera ferruginea & 169 & & & 6 & 157 & 6 & 4.000 & 0.267 & 6.68 & 4.469 \\
\hline Lentorbis carringtoni & 8 & & & & 8 & & 4.000 & 0.000 & 0.00 & 4.469 \\
\hline Lentorbis junodi & 12 & & & & 12 & & 4.000 & 0.000 & 0.00 & 4.469 \\
\hline Segmentorbis kanisaensis & 9 & & & & 9 & & 4.000 & 0.000 & 0.00 & 4.469 \\
\hline Chambardia petersi & 28 & & & 1 & 26 & 1 & 4.000 & 0.272 & 6.80 & 4.469 \\
\hline Cleopatra ferruginea & 73 & & & & 71 & 2 & 4.027 & 0.164 & 4.08 & 4.598 \\
\hline Lanistes ovum & 41 & & & & 38 & 3 & 4.073 & 0.264 & 6.47 & 4.813 \\
\hline
\end{tabular}


Figure 2

Decision tree of the frequency of occurrence of Physa acuta for each variable as compared to the frequency of

occurrence of all

the other species in

the database of the NFSC.

0 : percentages and frequencies of all other species,

1: percentages and frequencies of

P. acuta. Water-

bodies: A: channel,

$B$ : concrete dam,

C: dam, D: ditch,

E: irrigation furrow,

F: pan, G: pond,

$H$ : quarry, l: river,

$J$ : spring, K: stream,

L: swamp, M: vlei, $N$ : waterhole

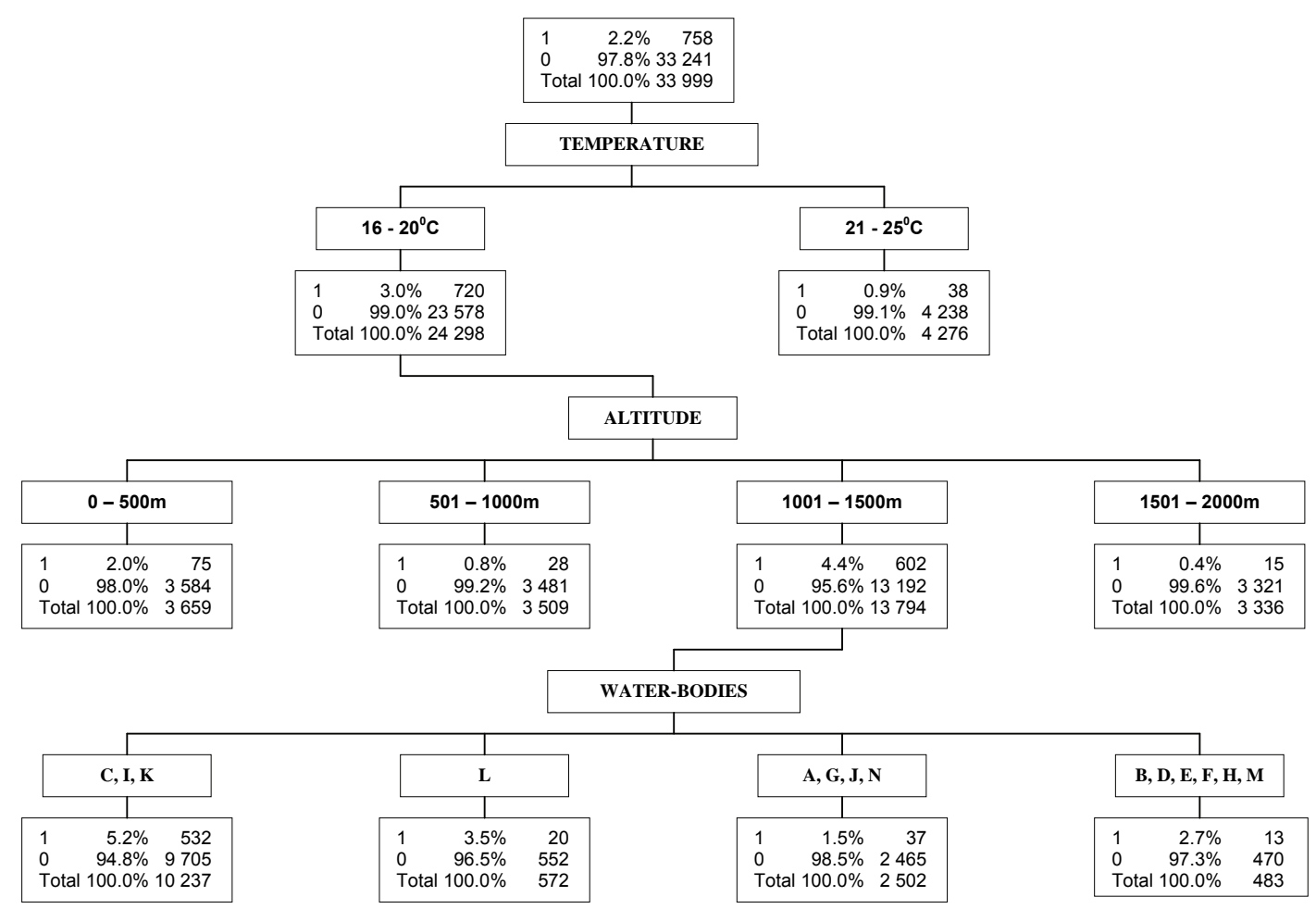

intervals (chi-square values ranging from $\chi=9.43, d f=1 ; \mathrm{p}<0.05$ to $\chi=219.49, d f=1 ; \mathrm{p}<0.05$ ). The temperature index (3.048) calculated for $P$. acuta ranked it $19^{\text {th }}$ out of 53 species in respect of its association with low temperatures and the effect sizes indicated that this species differed significantly $(w=/>0.5)$ in this regard from 38 of the other species (Table 5). The effect size values calculated for all the other parameters to determine the possible effect they could have had on the geographical distribution of P. acuta as depicted in Fig. 1, are presented in Tables 1 to 4. From these values it can be deduced that altitude, temperature and type of water-body played an important role in this respect $(w=/>0.5)$. These findings are supported by the results of the decision tree analysis (Fig. 2) which selected the same 3 factors as being important in establishing the geographical distribution of this species as reflected by the samples in the NFSC database.

\section{Discussion}

The decision-tree analysis grouped dams, rivers and streams together and indicated that the frequency of occurrence of $P$. acuta in these three types of water-bodies in the temperature interval ranging from 16 to $20^{\circ} \mathrm{C}$ and the altitude interval ranging from 1001 to $1500 \mathrm{~m}$ differed significantly from all the other types of water-body (Fig. 2). This supports the statement by Brown (1994) that $P$. acuta is particularly common in both stagnant and flowing waters. An important attribute to exploit both lotic and lentic water-bodies is its relatively high tolerance of current velocities reported by Appleton (2003). It is therefore not surprising that a considerable number of samples of $P$. acuta in our database were recovered from water-bodies with current velocities ranging from slow to fast flowing (Table 2). The apparent lack of any association with submerged aquatic vegetation (Appleton, 2003) is supported by the fact that 36 of the samples in the NFSC database were collected in habitats reported to be without any higher vegetation. However, $P$. acuta commonly occurs on the roots of floating water hyacinths
(Eichhornia crassipes) in backwaters of the Vaal River as observed during regular excursions with our students.

Although coordinated, extensive freshwater snail surveys by government and local health authorities were discontinued during the early $1980 \mathrm{~s}$, samples of $P$. acuta from 21 new loci were recorded in the NFSC database since the report by De Kock et al. (1989) (Fig. 1). One reason for its success as invader is suggested to be its high fecundity rate reported by Appleton and Brackenbury (1989) which proved to be superior to that of several common indigenous pulmonates, including Bulinus tropicus which is considered to be the most widespread freshwater snail in South Africa (De Kock et al., 2002). Physa acuta has become one of the most abundant snail species in the Vaal River over the past decade and has also been recovered in several small waterbodies within the Potchefstroom Municipal boundaries (NorthWest Province); however, it has not yet been found in the Mooi River (a tributary of the Vaal River) which meanders through Potchefstroom. This is rather surprising in view of its capability to migrate rapidly upstream as established by Appleton and Branch (1989) in the Liesbeeck River (Western Cape Province). Its slow progress in invading the Kruger National Park, as compared to other invasive snail species, was also observed by the authors during the surveys mentioned earlier. This could possibly be explained by the fact that $P$. acuta, commonly known as the 'sewage snail', seems to have difficulty in establishing itself far away from human activities and in Africa is associated with polluted water (Brown, 1994). From their studies in the Umsindusi River (KwaZulu-Natal) Brackenbury and Appleton (1993) concluded that $P$. acuta is better equipped than the indigenous snail species for establishing itself in newly disturbed habitats and may have become, like other invasives, a species associated with man. This could account for its absence in the relatively less disturbed habitats in the Mooi River and also for its slow progress in invading the water-bodies in the Kruger National Park where the impact of human activities is relatively small.

Scrutiny of the results in Table 5 shows that the most successful alien invader freshwater snail species in South Africa, 
L. columella (De Kock et al., 1989) was recovered from habitats located in loci falling within four of the temperature intervals, while the samples of $P$. acuta were recorded from only two of these intervals. Whether this reflects a narrower tolerance range in respect of temperature than that of $L$. columella and therefore could possibly have contributed to its more limited geographical distribution in South Africa than that of the latter species, needs further investigation.

In spite of a number of attributes contributing towards its success as an invader, amongst others a superior and adaptable reproductive ability, tolerance of higher current velocities than its indigenous counterparts (Brackenbury and Appleton, 1993) and rapid directional movement (Appleton 2003), the results of a recent study to establish the progress of alien invasive snail species in the Kruger National Park suggest that $P$. acuta might be a less aggressive invader than either Aplexa marmorata or Tarebia granifera (De Kock and Wolmarans, 2007). In view of the alarming progress that T. granifera has been making in invading water-bodies in the Kruger National Park, as observed by the authors during the surveys mentioned earlier and in KwaZulu-Natal (Appleton, 2005) since its presence in South Africa was first reported by Appleton and Nadasan (2002), its ecological impact could be far greater than that of $P$. acuta that has been present in South Africa for more than 6 decades.

The asynchronous nature of the collected material in the database could have an impact upon ecological variables and could confound some of the observations and conclusions drawn from the data. It is therefore unfortunate that the large-scale and routine coordinated snail surveys conducted in South Africa by state and local health authorities were discontinued in the early 1980s. At this point in time nobody really knows whether the intermediate host snails of medically and veterinary important parasitic diseases such as schistosomiasis and fascioliasis have extended the range of their geographical distribution in South Africa. Serious efforts should also be made to keep track of the progress made in their invasion of new water-bodies by the number of introduced alien mollusc species already present in South Africa. From the results of routine surveys, the database of the NFSC could be updated and monitoring of economically important snail-borne diseases at public health levels could also be facilitated.

\section{Acknowledgements}

The authors wish to thank the following persons and institution: Professors HS Steyn, head of the Statistical Consulting Service and DA de Waal of the Centre for Business Mathematics and Informatics of the of the North-West University, Potchefstroom Campus for their assistance in processing the data and the NorthWest University for infrastructure and financial support.

\section{References}

APPLETON CC (2003) Alien and invasive fresh water Gastropoda in South Africa. Afr. J. Aquat. Sci. 28 69-81.

APPLETON CC (2005) Invasive Freshwater Invertebrates in South Africa. Plenary address to the Congress of the Zoological Society of Southern Africa. July 2005, Grahamstown.

APPLETON CC and BRACKENBURY TD (1998) Introduced freshwater gastropods in Africa with special reference to Physa acuta. In: Madsen H, Appleton CC and Chimbari M (eds.) Proc. Workshop on Medical Malacology in Africa. September 1997, Harare, Zimbabwe. Danish Bilharziasis Laboratory, Danida, Denmark. 22-26. APPLETON CC, BRACKENBURY TD and TONIN AFG (1989) Physa mosambiquensis (Clessin, 1886) rediscovered? S. Afr. Tydskr. Dierk. 24 340-344

APPLETON CC and BRANCH GM (1989) Upstream migration by the invasive snail Physa acuta in Cape Town, South Africa. S. Afr. J. Sci. 85 189-190.

APPLETON CC and DANA P (2005) Re-examination of Physa mosambiquensis Clessin, 1886 and its relationship with other Aplexinae (Pulmonata: Physidae) reported from Africa. Afr. Invertebr. 46 71-83.

APPLETON CC and NADASAN DS (2002) First report of Tarebia granifera (Lamarck, 1816) (Gastropoda: Thiaridae) from Africa. J. Mollusc. Stud. 68 399-402.

BRACKENBURY TD and APPLETON CC (1991) Effect of controlled temperatures on gametogenesis in the gastropods Physa acuta (Physidae) and Bulinus tropicus (Planorbidae). J. Mollusc. Stud. 57 461-469.

BRACKENBURY TD and APPLETON CC (1993) Recolonization of the Umsindusi River, Natal, South Africa, by the invasive gastropod, Physa acuta (Basommatophora, Physidae). J. Med. Appl. Malacol. 5 39-44

BREIMAN L, FRIEDMAN JH, OLSHEN RA and STONE CJ (1984) Classification and Regression Trees. Chapman and Hall, UK.

BROWN DS (1994) Freshwater Snails of Africa and Their Medical Importance (Revised $2^{\text {nd }}$ edn.) Taylor \& Francis, London.

COHEN J (1977) Power Analysis for the Behaviour Sciences (Revised edn.) Academic Press, Orlando.

CONNOLLY M (1939) A monographic survey of the South African non-marine Mollusca. Ann. S. Afr. Mus. 33 1-660.

DE KOCK KN, JOUBERT PH and PRETORIUS SJ (1989) Geographical distribution and habitat preferences of the invader freshwater snail species Lymnaea columella (Mollusca: Gastropoda) in South Africa. Onderstepoort J. Vet. Res. 56 271-275.

DE KOCK KN and WOLMARANS CT (1998) A re-evaluation of the occurrence of freshwater molluscs in the Kruger National Park. Koedoe 41 1-8.

DE KOCK KN and WOLMARANS CT (2005a) Distribution and habitats of the Bulinus africanus species group, snail intermediate hosts of Schistosoma haematobium and S. mattheei in South Africa. Water SA 31 (1) 117-126. http://www.wrc.org.za/downloads/watersa/2005/ Jan-05/1775.pdf

DE KOCK KN and WOLMARANS CT (2005b) Distribution and habitats of Bulinus depressus and possible role as intermediate host of economically important helminth parasites in South Africa. Water SA 31 (4) 491-496. http://www.wrc.org.za/downloads/watersa/2005/ Oct-05/1771.pdf

DE KOCK KN, WOLMARANS CT, BORNMAN M and MAREE D (2002) Verspreiding en habitats van Bulinus tropicus, tussengasheerslak van die peervormige bot Calicophoron microbothrium, in SuidAfrika. S. Afr. Tydskr. Natuurwet. Teg. 21 114-120.

DE KOCK KN, WOLMARANS CT and DU PREEZ LH (2002) Freshwater mollusc diversity in the Kruger National Park: a comparison between a period of prolonged drought and a period of exceptionally high rainfall. Koedoe 45 1-11.

DILLON RT (Jr), WETHINGTON AR, RHETT JM and SMITH TP (2002) Populations of the European freshwater pulmonate Physa acuta are not reproductively isolated from American Physa heterostropha or Physa integra. Invert. Biol. 121 226-234.

HAMILTON-ATTWELL VL, DE KOCK KN and VAN EEDEN JA (1970) The occurrence and distribution of Physa acuta Draparnaud in the Republic of South Africa. Wetenskaplike Bydraes van die Potchefstroomse Universiteit vir Christelike Hoër Onderwys, Reeks B: Natuurwetenskappe 26 1-11.

MADSEN H and FRANDSEN F (1989) The spread of freshwater snails including those of medical and veterinary importance. Acta Tropica. 46 139-146.

POTTS WJE (1999) Decision Tree Modeling Course Notes. SAS Institute Inc., Cary, USA.

WOLMARANS CT and DE KOCK KN (2006) The current status of freshwater molluscs in the Kruger National Park. Koedoe 49 39-44.

VAN BRUGGEN AC (1964) The distribution of introduced mollusc species in southern Africa. Beaufortia 11 161-169. 